TITLE:

\title{
Diversity, resource utilization, and phenology of fruiting bodies of litter-decomposing macrofungi in subtropical, temperate, and subalpine forests
}

\author{
$\operatorname{AUTHOR}(\mathrm{S})$ : \\ Osono, Takashi
}

\section{CITATION:}

Osono, Takashi. Diversity, resource utilization, and phenology of fruiting bodies of litterdecomposing macrofungi in subtropical, temperate, and subalpine forests. Journal of Forest Research 2014, 20(1): 60-68

\section{ISSUE DATE:}

2014-08-24

URL:

http://hdl.handle.net/2433/200206

\section{RIGHT:}

The final publication is available at Springer via http://dx.doi.org/10.1007/s10310-0140459-9.; この論文は出版社版でありません。引用の際には出版社版をご確認ご利用くだ さい。; This is not the published version. Please cite only the published version. 
1 Diversity, resource utilization, and phenology of fruiting bodies of

2 litter-decomposing macrofungi in subtropical, temperate, and subalpine forests

3

4 Takashi Osono

5

6 T. Osono

7 Center for Ecological Research, Kyoto University, Otsu, Shiga 520-2113 Japan

8 e-mail: tosono@ecology.kyoto-u.ac.jp

10 AbstractThe diversity, vegetative and reproductive characteristics, and phenology

11 of litter decomposing macrofungi (LDM) were compared between humus forms

12 and climatic regions. Fruiting bodies of LDM were examined for the forest floor of

13 subtropical (ST), cool temperate (CT), and subalpine (SA) forests in Japan. Field

14 surveys during one growing season yielded 35, 32, and 18 species in ST, CT, and

15 SA, respectively. Species richness was generally higher in mull than in moder

16 humus and in warmer than in cooler climate. A total of 10 fungal families were

17 observed, and species in the Mycenaceae dominated in the LDM assemblages at 
18 all study sites. A larger number of species fruited on deeper F layers of the forest

19 floor in SA than in ST, where $74 \%$ of species fruited directly on leaf litter. This

20 observation was consistent with the analysis of radiocarbon content in fruiting

21 bodies, implying that LDM tended to utilize older carbon accumulated at deeper

22 layers of the forest floor in cooler climates. Seasonal changes in the fruiting

23 frequency over a growing season exhibited similar two-peak patterns for all the

24 study sites, coinciding with the periods of rainfall and increasing and decreasing

25 air temperatures in early summer and autumn, respectively, but the fruiting

26 period extended longer in warmer than in cooler climate.

28 Keywords

Climate • Decomposition • Mycena • Radiocarbon •

29 Seasonal changes

30

31 Introduction

32

33 Litter-decomposing macrofungi (LDM) are major components of the diversity of

34 soil organisms in terrestrial ecosystems and play central roles in the 
35 decomposition of structural and soluble components in litter that often limit

36 carbon and nutrient cycling in soil (Osono 2007; van der Wal et al. 2013). A suite of

LDM with the ability to decompose lignin and other recalcitrant compounds are of particular importance because the colonization of litter materials by these fungi often stimulates the turnover of organic matter and nutrients in soil (Steffen et al. reliable and useful information about their taxonomy, diversity, and reproduction and have been surveyed for their diversity (e.g. Schmit et al. 1999; Mueller et al. 2007) and seasonal patterns (Murakami 1989; Yamashita and Hijii 2004) and for

44 the effects on them of vegetation (Hansen and Tyler 1992; Lange 1993; Såstad 1995), soil conditions (Tyler 1985; Rastin et al. 1990), and elevational gradient (Gómez-Hernández et al. 2012). Moreover, the observation of vegetative mycelia at the base of fruiting bodies can often yield insights into the substrate utilization and decomposing ability of LDM (Osono et al. 2011a). Currently, however, few

49 studies have investigated the diversity, vegetative and reproductive

50 characteristics, and phenology of LDM simultaneously and compared these

51 between humus forms and climatic regions. It is hypothesized that the pattern of 
52 diversity, substrate utilization, and phenology of fruiting bodies of LDM change

53 along gradients of soil conditions and climate.

The purpose of the present study was to investigate fruiting bodies of

55 LDM emerging from the forest floor of subtropical, cool temperate, and subalpine

56 forests in Japan. Field sampling of fruiting bodies over growing seasons yielded

57 information about the structure, diversity, and species composition of LDM

58 assemblages and seasonal patterns of occurrence. Each LDM species was recorded

59 for the soil layer from which its fruiting body emerged to examine the substrate

60 its vegetative mycelia utilized. Radiocarbon $\left({ }^{14} \mathrm{C}\right)$ contents of fruiting bodies were

61 measured for major LDM species to estimate the age of carbon (i.e. time since

62 death of plant litter) utilized by these species. The diameter of the pileus and the

63 length of the stipe were measured for fruiting bodies found in the three forest soils,

64 and possible roles of the size variation of fruiting bodies in the seasonal patterns

65 of fruiting bodies were discussed.

66 
Study site

70

71 Samples were collected from three sites in Japan: a subtropical forest (ST), a cool

72 temperate forest (CT), and a subalpine forest (SA). ST was located in Okinawa,

73 southern Japan. CT was located in Kyoto, Japan. In CT, two study plots were

74 established on the upper and lower parts of a northwest-facing slope

75 (approximately 200 m long). SA was located on Mt. Ontake, Gifu, Japan. Details

76 of the location, climatic conditions, and vegetation are given in Osono (submitted).

77 In summary, the three sites differed in mean annual temperature $\left(22^{\circ} \mathrm{C}, 9^{\circ} \mathrm{C}\right.$, and

$782^{\circ} \mathrm{C}$ in $\mathrm{ST}, \mathrm{CT}$, and $\mathrm{SA}$, respectively), seasonal patterns of change in air

79 temperature, and the duration of the growing season, but they received similar

80 amounts of precipitation annually. The study sites experience a rainy season from

81 May to June in ST and from June to July in CT and SA. Snow covers the forest

82 floor of CT from December to April and that of SA from mid-November to early

83 June. Table 1 shows properties of the forest floor of the study sites. The

84 accumulation of forest floor material, in terms of the depth and the mass, was in

85 the order: ST, CT (lower) < CT (upper) < SA, whereas the order was generally 
86

87

88

89

90 Study plot and field survey

91

92 A study plot of $50 \times 10 \mathrm{~m}\left(500 \mathrm{~m}^{2}\right)$ was laid out in each of ST, CT (upper), CT

93 (lower), and SA sites and was divided into 125 grids of $2 \times 2 \mathrm{~m}$. The study area of

$94500 \mathrm{~m}^{2}$ was found to be large enough to describe species richness of macrofungi in

95 CT sites, according to Okabe (1986). 1- to 2-month intervals from March 2007 to January 2008 in ST, nine times at 2to 4-week intervals from May to November 2001 in CT, and five times at 1-month

99 intervals from June to October 2008 in SA. On each sampling occasion, all fruiting

100 bodies encountered on the surface of the forest floor were recorded, excepting obviously immature or rotting ones. Records were kept of taxa and of grid number 
103 from which the fruiting bodies emerged (see Table $\mathrm{S} 1$ in Electronic

104 Supplementary Material). Fruiting bodies occurring on logs, twigs, or roots that

105 were fallen or buried were not recorded. Ascomycetes were omitted, but the

106 Xylariaceae on leaf litter were included because of their ligninolytic activity

107 (Osono et al. 2011b). In October and November 2011, fruiting bodies were

108 measured for the diameter of their pileus and length of their stipe at the three

109 sites. Identification was primarily made macroscopically after Imazeki et al.

111 (1988), Imazeki and Hongo (1987, 1989), and Hongo (1994). Small fruiting bodies

112 of Mycena and Marasmius that were difficult to distinguish and identify at the

113 species level in the field were classified at the genus or section level, which was

114 referred to as species in the present study for the sake of simplicity (but see

115 Discussion). Tissues of some fruiting bodies were further analyzed for the DNA

116 sequence of amplicons of rDNA ITS region obtained using primers ITS5 and ITS4

117 (White et al. 1990) and of the 28S rRNA gene D1/D2 region using primers D1

118 (Peterson 2000) and NL4 (O'Donnell 1993), according to the method of Hirose and

119 Osono (2006). The sequences determined were compared with the available rDNA 
120 sequences in the GenBank database by means of BLAST+ (Camacho et al. 2009)

121 and assigned taxonomically. The data of molecular analyses will be given in a

122 future paper.

123

The frequency of occurrence of LDM was calculated as a percentage of

124 incidences based on the number of grids in which the fruiting body was

125 encountered relative to the total number of grids (125) at each study site. Relative

126 frequency of an individual species was calculated as the percentage of its

127 frequency of occurrence with respect to the grand sum of the frequency of

128 occurrence of all species at each study site. Data of fruiting bodies of mycorrhizal

129 fungi were excluded from the following analyses.

130

131 Radiocarbon analysis

132

133 Samples of fruiting bodies were ground in a laboratory mill to make particles that

134 would pass through a $0.5-\mathrm{mm}$ screen and sent to the Institute of Accelerator

135 Analysis Ltd, Kanagawa, Japan, for accelerator mass spectrometry

136 measurements of radiocarbon. The methods are described in Hyodo et al. (2006). 
137 Radiocarbon values were reported as $\Delta{ }^{14} \mathrm{C}(\%)$, which is the part per-thousand

138 deviation from the activity of nineteenth century wood, and corrected for the

139 fractionation using stable carbon (C) isotope ratios of the samples. The method to estimate the carbon age of fruiting bodies of LDM followed

141 Hyodo et al. (2006). The carbon age of fruiting bodies of fungi was defined as the

142 time elapsed since $\mathrm{C}$ in their substrates was fixed from atmospheric $\mathrm{CO}_{2}$ by

143 primary producers. $\Delta^{14} \mathrm{C}$ values of samples were compared with those of

144 atmospheric $\mathrm{CO}_{2}$ recorded at Schauinsland, Germany, for 1976-97 (Levin and

145 Kromer 1997). I estimated the $\Delta^{14} \mathrm{C}$ values of atmospheric $\mathrm{CO}_{2}$ after 1997 by

146 extrapolation of the exponential function: $\Delta^{14} \mathrm{C}(t)=417 \times \exp (-t / 16.0)$, where $\mathrm{t}$ is

147 the year after 1974 (Levin and Kromer 1997). This method yielded two estimates

148 of the year of $\mathrm{C}$ fixation for the measured $\Delta^{14} \mathrm{C}$ values of fruiting bodies, one before

149 and another after the peak of bomb- $\Delta^{14} \mathrm{CO}_{2}$ in mid-1960s, and hence two carbon

150 ages (Hyodo et al. 2006). I adopted the carbon ages estimated from the year of C

151 fixation after the peak bomb $-\Delta^{14} \mathrm{C}$, because these estimated carbon ages were

152 compatible with the turnover rates of the forest floor (1.5 to 29.1 years in the

153 study sites, Table 1). 
155 Statistical analysis

156

157 The observed number of LDM species at each study site was denoted as $\mathrm{S}_{\text {obs. }}$ It

158 was possible that $\mathrm{S}_{\text {obs }}$ be underestimated when the abundance of fruiting bodies of

159 LDM encountered (i.e., the sampling effort) was low at any study site, compared

160 to other sites. To avoid this, I used an individual-based Coleman rarefaction curve

161 (Colwell and Coddington 1994) to depict the cumulative number of species versus

162 the observation of fruiting bodies (Fig. S2 in Electronic Supplementary Material).

163 In the present study, the number of observation of fruiting bodies was variable

164 among the study sites, ranging from 77 at CT (upper) to 620 observations at ST.

165 Thus, the study sites were compared for the estimated numbers of LDM species at

16677 observations (denoted as $\mathrm{S}_{\text {est }}$ ). Calculations were performed with $\mathrm{R}$ version

167 3.0.2 for Mac (R Development Core Team 2009) and its vegan package (Oksanen

168 2013).

170 following equations (Osono et al. 2002): $\mathrm{D}=1 / \Sigma \mathrm{P}_{i}^{2}, \mathrm{E}=\mathrm{D} / \mathrm{S}_{\mathrm{obs}}$, where $\mathrm{P}_{i}$ was a 
171 proportion of the frequency of occurrence of ith species to the sum of frequency of

172 all species.

173

Generalized linear models (GLMs) were used with a Gaussian

174 distribution to compare the size of fruiting bodies of LDM between the study sites.

175 The GLMs were performed with the glm function and with the glht function of the

$176 \mathrm{R}$ multcomp package for multiple comparisons with Tukey's test.

178 Results

179

180 Species richness and taxonomic composition

181

182 A total of 35,32 , and 18 species of LDM were observed ( $\mathrm{S}_{\text {obs }}$ ) in $\mathrm{ST}$, CT, and SA,

183 respectively; and in CT, 25 and 11 species were observed at lower and upper slopes,

184 respectively (see ESM; summarized in Table 2). The number of singleton species

185 (i.e. species encountered in only one grid) accounted for $17 \%$ to $49 \%$ of the total

186 number of species, in the order: ST $>\mathrm{CT}$ (lower) $>\mathrm{CT}$ (upper) $>\mathrm{SA}$ (Table 2).

187 Simpson's diversity index was in the order: $\mathrm{ST}>\mathrm{SA}>\mathrm{CT}$ (lower) $>\mathrm{CT}$ (upper), 
188 and equitability was in the order: $\mathrm{CT}$ (upper) $>\mathrm{SA}>\mathrm{ST}>\mathrm{CT}$ (lower) (Table 2).

189 Rarefaction analysis showed that the estimated number of LDM species ( Sest )

190 were higher in mull [ST and CT (lower)] than in moder humus [CT (upper) and

191 SA] (Table 2).

192

A total of 10 fungal families were observed: five, seven, five, and five

193 families in ST, CT (lower), CT (upper), and SB, respectively (Table 2). Mycena

194 species in the Mycenaceae dominated in the LDM assemblages at each study site

195 in terms of the number of species (27\% to $50 \%$ of the total number of species; Table

196 2) and the relative frequency (Fig. 1). The frequencies of occurrence of two major

197 Mycena species reached more than 90\% (i.e. the fruiting bodies of these species

198 occurred in more than $90 \%$ of the 125 grids) in ST and between $13.6 \%$ to $60.8 \%$ in

199 CT and SB (see ESM). These major Mycena species were followed by species in

200 Marasmiaceae in ST and CT (upper), by species in Agaricaceae in CT (lower), and

201 by species in Hymenogasteraceae in SA (Table 2; Fig. 1).

202

203 Soil layer from which macrofungi fruited 
205 Soil layer from which LDM fruited differed among the study sites: more number of

206 LDM species that fruited from deeper layers of the forest floor at cooler climate.

207 That is, 74\% (26/35) of species in ST fruited on the surface L layer (i.e. emerging

208 directly on leaf litter), whereas $73 \%$ to $92 \%$ from the border between $\mathrm{L}$ and $\mathrm{F}$

209 layers in CT, and 78\% from the F layer in SA (Table 2) did so. Those that fruited

210 on L layer were 'component-restricted' sensu Osono (2007) in that individual

211 mycelia were limited in extent by the physical boundaries of the litter component

212 they occupied. Conversely, those that fruited on the L-F border and F layer were

213 'component-non-restricted' in that the entire forest floor, rather than an

214 individual litter component, provided a habitat for the fungi.

215

216 Radiocarbon content

218 The mean $\Delta{ }^{14} \mathrm{C}$ values of fruiting bodies ranged between $48.2 \%$ and $139.7 \%$ (Table

219 3), indicative of the fungal uptake of bomb- $\Delta^{14} \mathrm{C}$ that was primarily derived from

220 the litter that these LDM utilized (Hyodo et al. 2006). The carbon age of fruiting

221 bodies from ST ranged from 2.8 to 9.0 years. These values suggested that these 
222 LDM utilized leaves that died at least 1.8 to 8.0 years previously, because tree

223 leaves in ST were mostly evergreen and had leaf longevity of more than one year.

224 In contrast, the carbon age of fruiting bodies from CT ranged from 3.6 to 11.4

225 years, suggestive of the utilization of deciduous leaves that died as long as 11.4

226 years before. The carbon age of fruiting bodies from SA reached as old as 20.3

227 years, suggestive of the utilization of evergreen leaves (maximum ages of 6 to 11

228 years, Mori and Takeda 2004) that had died at least 10 years before. These results,

229 together with the results of direct observation of fruiting bodies, suggested that

230 LDM tended to utilize older carbon accumulated at deeper layers of the forest

231 floor in cooler climates.

232

233 Size and phenology of fruiting bodies

234

235 The mean size of the fruiting bodies, measured as the diameter of pileus and

236 length of stipe, was significantly different among the study sites (ANOVA, p<0.05),

237 in the order: CT $>$ SA $>$ ST (Table 4). This was accounted for by the difference in

238 size of the major Mycena species in these study sites (Table 4). 
240 than in CT or SA (Fig. 2). Seasonal changes in the frequency over a growing

241 season exhibited similar two-peak patterns for all the study sites: a peak during

242 the rainy season in early summer and another in autumn (Fig. 2). That is, the

243 peaks were found in June and in September to January at ST, in June and in

244 September to November at CT, and in July and in September-October at SA. The

245 number of LDM species followed similar seasonal patterns as the frequency of

246 occurrence of fruiting bodies, except that there was a rapid increase in the

247 number of species in June in ST.

248

The major LDM species differed in the seasonal patterns of their

249 frequency of occurrence over a growing season (Fig. 3). In ST, fruiting bodies of

250 some major species, such as Mycena sp.ST1 and Marasmius sp.ST1, occurred

251 relatively constantly over the growing season, whereas Mycena sp.ST2, Xylaria

252 sp.ST1, and Crinipellis sp.ST1 displayed fruiting peaks in June and/or in

253 September to January. In CT and SA, the frequencies of major species increased

254 once in autumn (My. polygramma in CT and My. epipterygia, G. atkinsoniana, 
256 in CT and My. aurantiidisca in SA) over the growing season.

257

258 Discussion

259

260 The numbers of species of LDM observed in CT and SA (Table 2) were within the

261 range reported previously in temperate and boreal forests (Tyler 1985; Hintikka

262 1988; Villeneuve et al. 1989; Brunner et al. 1992; Miyamoto et al. 2000;

263 Outerbridge 2002; Richard et al. 2004; Gates et al. 2011; O'Hanlon and

264 Harrington 2012), despite the short survey period (one growing season) at each

265 study site. The dominance of Mycena in terms of the number of species and the

266 frequency of occurrence is consistent with these previous reports. López-Quintero

267 et al. (2012) also observed the occurrence of Mycena and Marasmius species in

268 Amazon tropical rainforests, but comparative studies on the diversity of LDM in

269 tropical and subtropical forests have been relatively scarce, especially in Asian

270 tropical regions (Mueller et al. 2007).

The number of observed and estimated species and Simpson's diversity index of LDM were generally higher in mull than in moder humus (Table 2). This 
273 was evident in CT, where the richness of LDM was higher at the lower (mull) than

274 the upper (moder) slope. The two most frequent species were common to the two

275 sites, so that infrequent species accounted for the low similarity of species

276 composition (Table 2, Fig. 1). Rastin et al. (1990) also compared LDM between the

277 lower and upper slope of a spruce forest in Germany and reported that the species

278 composition was generally similar between those parts, in contrast to the results

279 of the present study. This discrepancy may be partly due to the slope length [30 $\mathrm{m}$

280 in Rastin et al. (1990) versus $200 \mathrm{~m}$ in the present study]. The causal factors for

281 the higher LDM richness in mull of CT remain unclear, but the relatively

282 favorable moisture condition at the lower slope could possibly favor the fruiting

283 and co-occurrence of more LDM species on the forest floor.

The LDM diversity was generally higher in warmer than in cooler

285 climates, suggesting a climatic gradient of diversity. Similar climatic gradients of

286 fungi have been found for litter decomposing microfungi (Osono 2011) and foliar

287 endophytic fungi (Arnold and Lutzoni 2007; Ikeda et al. 2014). At least two explanations are possible for the putative higher diversity of fruiting bodies of

289 LDM in warmer locations. First, the warmer condition throughout the year and 
290 lack of snow cover period in winter of ST can favor the fruiting (and possibly, the

291 co-existence) of multiple LDM. This is illustrated in the fruiting phenology of

292 major LDM species (Fig. 3): fruiting bodies occurred throughout the year or with

293 multiple peaks in ST, whereas in CT and SA they peaked once or twice over the

294 growing season. Such differences may be partly due to suitability of the climatic

295 conditions for establishment, growth, and fruiting of more LDM species in ST.

296

Secondly, differences in the quality of resources can also affect the

297 diversity of LDM. I found that LDM from a cooler climate produced fruiting bodies

298 that originated from deeper soil layers than those from a warmer climate (Table 2).

299 In accordance with this, LDM from a cooler climate appeared to utilize more aged

300 dead carbon than those from a warmer climate (Table 3). Given that more

301 decomposed materials in deeper layers contain less readily available organic

302 carbon sources, such as non-lignified holocellulose and soluble carbohydrates

303 (Berg 1986; Osono et al. 2003), the utilization of resources at deeper layers in a

304 cooler climate may be unfavorable for the growth and fruiting of LDM. Osono

305 (2011) demonstrated that non-ligninolytic microfungi are major components of

306 fungal assemblages on recently fallen litter in a cooler climate, suggesting that 
307 ligninolytic LDM are less competitive for readily available resources in the

308 surface litter in a cooler climate (Osono 2007). The dominance in SA of conifers,

309 whose needles are rich in secondary compounds that inhibit the growth of LDM

310 (Bağci and Diğrak 1996), can also affect the colonization of the L layer by LDM.

Two peaks were found for the occurrence of fruiting bodies over a growing

312 season at all three climates, but the fruiting period extended longer at warmer

313 than at cooler climates (Fig. 2). The two peaks coincided with the period of rainfall

314 and with the increasing and decreasing air temperatures in early summer and

315 autumn, respectively, at the three forest sites. Similar one- or two-peak patterns

316 of fruiting of LDM have commonly been found in temperate forests (Okabe 1983;

317 Straatsma et al. 2001; Yamashita and Hijii 2004; Gates et al. 2011).

The fruiting phenology of major Mycena species may also be associated

319 with the size of fruiting bodies. For example, Mycena species with smaller fruiting

320 bodies fruited more frequently over a growing season than those with larger ones;

$321 M$. filopes in CT and $M$. aurantiidisca in SA with smaller fruiting bodies showed two peaks, whereas $M$. polygramma in CT and $M$. epipterygia in SA with larger

323 fruiting bodies showed only one peak in autumn (Fig. 3, Table 4), and even 
324 smaller Mycena sp. ST1 and ST2 in ST fruited throughout the growing season.

325 Because the production of larger fruiting bodies should require more resources to

326 be utilized, the size of fruiting bodies can set a limit on the reproduction. This

327 discussion is obviously speculative, however, as few data have been available

328 regarding the population structure and reproductive biology of individual LDM

329 species. More studies are needed to examine the life history strategy of LDM,

330 especially in tropical and subtropical regions.

332 Acknowledgments

I thank Dr. D. Hirose and Dr. T. Miyamoto for help with

333 the identification of macrofungi; Dr. F. Hyodo for useful discussion of radiocarbon

334 analysis; Dr. A. Takashima and staff at the Yona Experimental Forest, University

335 of the Ryukyus for help with fieldwork at ST; Dr. Y. Fukasawa and staff at Ashiu

336 Experimental Forest, Kyoto University for help with fieldwork at CT; and Dr.

337 Elizabeth Nakajima for critical reading of the manuscript. This study received

338 partial financial support from the Ministry of Education, Culture, Sports, Science,

339 and Technology of Japan (MEXT) (No. 19780114), The Sumitomo Foundation,

340 Nissan Global Foundation, Nippon Life Inst. Foundation, and the Grants for 
341 Excellent Graduate Schools, MEXT, Japan (12-01) to Kyoto University.

342

343 References

344

345 Arnold AE, Lutzoni F (2007) Diversity and host range of foliar endophytes: are tropical leaves biodiversity hotspots? Ecology 88:541-549

347 Bağci E, Diğgrak M (1996) Antimicrobial activity of essential oils of some Abies (Fir) species from Turkey. Flavour Fragr J 11:251-256

349 Berg B (1986) Nutrient release from litter and humus in coniferous forest soils - a mini review. Scand J For Res 1:359-369

351 Brunner I, Brunner F, Laursen GA (1992) Characterization and comparison of macrofungal communities in an Alnus tenuifolia and an Alnus crispa forest in Alaska. Can J Bot 70:1247-1258

354 Camacho C, Coulouris G, Avagyan V, Ma N, Papadopoulos J, Bealer K, Madden TL (2009) BLAST+: architecture and applications. BMC Bioinformatics $10: 421$

357 Cowell RK, Coddington JA (1994) Estimating terrestrial biodiversity through 
359 Fukasawa Y, Katsumata S, Mori AS, Osono T, Takeda H (2014) Accumulation and decay dynamics of coarse woody debris in a Japanese old-growth 361 subalpine coniferous forest. Ecol Res 29:257-269 Diversity and phenology of the macrofungal assemblages supported by litter in a tall, wet Eucalyptus obliqua forest in southern Tasmania, Australia. Fungal Ecol 4:68-75 macromycete community assemblage along an elevation gradient: options for fungal gradient and metacommunity analyses. Biodivers Conserv 21:2247-2268

370 Hansen PA, Tyler G (1992) Statistical evaluation of tree species affinity and soil preference of the macrofungal flora in south Swedish beech, oak and hornbeam forest. Crypt Bot 2:355-361

373 Hintikka V (1988) On the macromycete flora in oligotrophic pine forests of different ages in south Finland. Acta Bot Fennica 136:89-94 
375 Hirose D, Osono T (2006) Development and seasonal variations of Lophodermium populations on Pinus thunbergii needle litter. Mycoscience 47:242-247

Hyodo F, Tayasu I, Wada E (2006) Estimation of the longevity of C in terrestrial detrital food webs using radiocarbon $\left({ }^{14} \mathrm{C}\right)$ : how old are diets in termites? Functional Ecol 20:385-393

381

Ikeda A, Matsuoka S, Masuya H, Mori AS, Hirose D, Osono T (2014) Comparison of the diversity, composition, and host recurrence of xylariaceous endophytes in subtropical, cool temperate, and subboreal regions in Japan. Popul Ecol in press Imazeki R, Hongo T (1987) Colored Illustration of Mushrroms of Japan. Vol. I. Hoikusha, Tokyo, Japan (in Japanese)

387 Imazeki R, Hongo T (1989) Colored Illustration of Mushrooms of Japan. Vol. II. Hoikusha, Tokyo, Japan (in Japanese) Japan (in Japanese)

391 Lange M (1993) Maromycetes under twelve tree species in ten plantations on 

various soil types in Denmark. Opera Bot 120:1-53

393 Levin I, Kromer B (1997) Twenty years of atmospheric ${ }^{14} \mathrm{CO}_{2}$ observations at 394 Schauinsland station, Germany. Radiocarbon 39:205-218

395 396 398 399 400 401 402 403 404 405 406 Macrofungal diversity in Colombian Amazon forests varies with regions and regimes of disturbance. Biodivers Conserv 21:2221-2243

Miyamoto T, Igarashi T, Takahashi K (2000) Lignin-degrading ability of litter-decomposing basidiomycetes from Picea forests of Hokkaido. Mycoscience 41:105-110

Mori A, Takeda H (2004) Functional relationships between crown morphology and within-crown characteristics of understory saplings of three codominant conifers in a subalpine forest in central Japan. Tree Physiol 24:661-670

Mueller GM, Schmit JP, Leacock PR, Buyck B, Cifuentes J, Desjardin DE, Halling RE, Hjortstam K, Iturriaga T, Larsson KH, Lodge DJ, May TW, Minter D, Rajchenberg M, Redhead SA, Ryvarden L, Trappe JM, Watling R, Wu Q (2007) Global diversity and distribution of macrofungi. Biodivers Conserv $16: 37-48$ 
409 Murakami Y (1989) Spatial changes of species composition and seasonal fruiting of the Agaricales in Castanopsis cuspidata forest. Trans Mycol Soc Japan 30:89-103

412

O'Donnell K (1993) Fusarium and its near relatives. In: Reynolds DR, Taylor JW (eds) The fungal holomorph: mitotic, meiotic and pleomorphic speciation in fungal systematics. CAB International, Wallingford, UK, pp 225-233

415 O'Hanlon R, Harrington TJ (2012) Macrofungal diversity and ecology in four Irish forest type. Fungal Ecol 5;499-508

417 Okabe H (1983) Mycosociological research of Agaricales in natural forests (II) Seasonal changes on each stand and life form. Bull Kyoto Univ Forest 53:20-32 (in Japanese with English abstract)

420 Okabe H (1986) Ecological study of distribution of fungi within forests. PhD thesis, Kyoto University, Kyoto (in Japanese)

422 tutorial. $\quad$ http://cc.oulu.fi/ jarioksa/opetus/metodi/vegantutor.pdf (accessed 14.5.14)

425 Osono $\mathrm{T}$ (2007) Ecology of ligninolytic fungi associated with leaf litter 
decomposition. Ecol Res 22:955-974

427 Osono T (2011) Diversity and functioning of fungi associated with leaf litter decomposition in Asian forests of different climatic regions. Fungal Ecol $4: 375-385$

430 Osono T. Mycelial biomass in the forest floor and soil of subtropical, temperate, and subalpine forests. J For Res:submitted

432 Osono T, Hobara S, Fujiwara S, Koba K, Kameda K (2002) Abundance, diversity, and species composition of fungal communities in a temperate forest affected by excreta of the Great Cormorant Phalacrocorax carbo. Soil Biol Biochem 34:1537-1547

436 Osono T, Ono Y, Takeda H (2003) Fungal ingrowth on forest floor and resource availability and moisture condition. Soil Biol Biochem $35: 1423-1431$

440 Osono T, Hobara S, Hishinuma T, Azuma JI (2011a) Selective lignin decomposition and nitrogen mineralization in forest litter colonized by 
443 Osono T, To-Anun C, Hagiwara Y, Hirose D (2011b) Decomposition of wood, petiole and leaf litter by Xylaria species from northern Thailand. Fun Ecol $4: 210-218$

446 Outerbridge RAM (2002) Macrofungus ecology and diversity under different conifer monocultures on southern Vancouver Island. PhD thesis, University of Victoria

Peterson SW (2000) Phylogenetic analysis of Penicillium species based on ITS and lsu-rDNA nucleotide sequences. In: Samson RA, Pitt JI (eds) Integration of modern taxonomic methods for Penicillium and Aspergillus classification. Harwood, Amsterdam, the Netherland, pp 163-178

453 Rastin N, Schlechte G, Hüttermann A (1990) Soil macrofungi and some soil biological, biochemical and chemical investigationson the upper and lower slope of a spruce forest. Soil Biol Biochem 22:1039-1047

R Development Core Team (2009) R: a language and environment for statistical computing. http://www.r-project.org/ (accessed 14.5.14)

458 Richard F, Moreau PA, Selosse MA, Gardes M (2004) Diversity and fruiting patterns of ectomycorrhizal and saprobic fungi in an old-growth 
Såstad SM (1995) Fungi - vegetation relationships in a Pinus sylvestris forest in central Norway. Can J Bot 73:807-816

Schmit JP, Murphy JF, Mueller GM (1999) Macrofungal diversity of a temperate oak forest: a test of species richness estimators. Can J Bot 77:1014-1027 oak (Quercus petraea) leaf litter by litter-decomposing basidiomycetes. Res Microbiol 158:447-455

Straatsma G, Ayer F, Egli S (2001) Species richness, abundance, and phenology of fungal fruit bodies over 21 years in a Swiss forest plot. Mycol Res

Takeda H, Kaneko N (1988) Patterns of soil humus accumulation in forests. I. Mull and moder types humus in a broad-leaved forest. Bull Kyoto Univ Forest 60:33-45 (in Japanese with English abstract) observations on decomposing litter in mor humus form in a subalpine 
coniferous forest. Ecol Res 12:289-300

478

479

480

481

482

483

484

485

486

487

488

489

490

491

492

493

Tsukamoto J (1996) Soil macro-invertebrates and litter disappearance in a Japanese mixed deciduous forest and comparison with European deciduous forests and tropical rainforests. Ecol Res 11:35-50

Tyler G (1985) Macrofungal flora of Swedish beech forest related to soil organic matter and acidity characteristics. For Ecol Manag 10:13-29

Valášková V, Šnajdr J, Bittner B, Cajthaml T, Merhautová V, Hofrichter M, Baldrian P (2007) Production of lignocellulose-degrading enzymes and degradation of leaf litter by saprotrophic basidiomycetes isolated from a Quercus petraea forest. Soil Biol Biochem 39:2651-2660

Van der Wal A, Geydan TD, Kuyper TW, de Boer W (2013) A thready affair: linking fungal diversity and community dynamics to terrestrial decomposition processes. FEMS Microbiol Rev 37:477-494

Villeneuve N, Grandtner MM, Fortin JA (1989) Frequency and diversity of ectomycorrhizal and saprophytic macrofungi in the Laurentide Mountains of Quebec. Can J Bot 67:2616-2629

White TJ, Bruns T, Lee S, Taylor JW (1990) Amplification and direct sequencing 
of fungal ribosomal RNA genes for phylogenetics. In: Innis MA, Gelfand DH, Sninsky JJ, White TJ (eds) PCR Protocols: a Guide to Methods and

Xu X, Tokashiki Y, Enoki T, Hirata E (1998a) Characteristics of nutrient accumulation in forest floor under evergreen broadleaved forests in

500 Xu X, Enoki T, Tokashiki Y, Hirata E (1998b) Litterfall and the nutrient returns in evergreen broadleaved forests in Northern Okinawa Island. Sci Bull Fac

503 Yamashita S, Hijii N (2004) Relationships between seasonal appearance and longevity of fruitbodies of Agaricales and meteorological factors in a 
Osono Table 1

Table 1. Forest floor and field survey of fruiting bodies in the study sites.

\begin{tabular}{lccc}
\hline Site & ST & CT & SA \\
\hline Humus type & Mull & Mull (lower), & Moder $^{\mathrm{b}}$ \\
& & Moder (upper)a & \\
Depth of L layer $(\mathrm{cm}) \mathrm{c}$ & $1.1 \pm 0.1$ & $1.2 \pm 0.1$ & $2.7 \pm 0.3$ \\
Depth of FH layer $(\mathrm{cm}) \mathrm{c}$ & $1.0 \pm 0.2$ & $4.0 \pm 0.4$ & $13.4 \pm 1.2$ \\
Forest floor mass $(\mathrm{Mg} / \mathrm{ha})$ & $12.0^{\mathrm{d}}$ & 7.7 (lower) & $104.6^{\mathrm{f}}$ \\
& & 33.3 (upper)e & \\
Leaf fall mass $(\mathrm{Mg} / \mathrm{ha} / \mathrm{yr})$ & $7.95^{\mathrm{d}}$ & 4.10 (lower) & $3.59^{\mathrm{f}}$ \\
& & 3.20 (upper)e & \\
Turnover time $(\mathrm{yr}) \mathrm{g}$ & 1.5 & 1.9 (lower) & 29.1 \\
& & 10.4 (upper) & \\
\hline
\end{tabular}

aTakeda and Kaneko (1988). ' ${ }^{\text {TTian et }}$ al. (1997). 'Values are means \pm standard errors $(n=20)$. Measurement was carried out in the three study sites in October 2012. Values of CT were from the lower slope. ${ }^{\mathrm{Xu}}$ et al. (1998a, 1998b). eTsukamoto (1996). fFukasawa et al. (2014). gTurnover time = forest floor mass / annual leaf fall mass. 
Osono Table 2

Table 2. Assemblage structure and family composition of macrofungi and the soil layer from which fruiting bodies occurred. Numbers of macrofungal species are indicated for fungal families and the litter layers. Numbers in parentheses indicate the proportion relative to the observed number of species. Values of $\mathrm{S}_{\text {est }}$ indicate means \pm standard deviations. See text for $\mathrm{S}_{\text {est }}$.

\begin{tabular}{|c|c|c|c|c|}
\hline & $\mathrm{ST}$ & CT (lower) & CT (upper) & SA \\
\hline \multicolumn{5}{|l|}{ Diversity } \\
\hline $\begin{array}{l}\text { Observed number of } \\
\text { species }\left(\mathrm{S}_{\mathrm{obs}}\right)\end{array}$ & 35 & 25 & 11 & 18 \\
\hline Singleton species & $17(49)$ & $11(44)$ & $4(36)$ & $3(17)$ \\
\hline Simpson's D & 7.68 & 4.47 & 3.40 & 4.86 \\
\hline Equitability & 0.22 & 0.18 & 0.31 & 0.27 \\
\hline $\begin{array}{l}\text { Estimated number } \\
\text { of species }\left(\mathrm{S}_{\mathrm{est}}\right)\end{array}$ & $14.2 \pm 2.1$ & $17.2 \pm 2.0$ & $11.0 \pm 0.0$ & $11.9 \pm 1.7$ \\
\hline \multicolumn{5}{|l|}{ Family composition } \\
\hline Mycenaceae & $13(37)$ & $10(40)$ & $3(27)$ & $9(50)$ \\
\hline Marasmiaceae & $12(34)$ & $3(12)$ & $3(27)$ & $2(11)$ \\
\hline Agaricaceae & $3(9)$ & $6(24)$ & $2(18)$ & $1(6)$ \\
\hline Tricholomataceae & $5(14)$ & $2(8)$ & $0(0)$ & $3(17)$ \\
\hline Strophariaceae & $0(0)$ & $1(4)$ & $2(18)$ & $0(0)$ \\
\hline Psathyrellaceae & $0(0)$ & $2(8)$ & $0(0)$ & $0(0)$ \\
\hline Pluteaceae & $0(0)$ & $1(4)$ & $0(0)$ & $0(0)$ \\
\hline Hygrophoraceae & $0(0)$ & $0(0)$ & $1(9)$ & $0(0)$ \\
\hline Hymenogasteraceae & $0(0)$ & $0(0)$ & $0(0)$ & $1(6)$ \\
\hline Xylariaceae & $1(3)$ & $0(0)$ & $0(0)$ & $0(0)$ \\
\hline Unidentified & $1(3)$ & $0(0)$ & $0(0)$ & $2(11)$ \\
\hline \multicolumn{5}{|l|}{ Soil layer } \\
\hline L layer & $26(74)$ & $0(0)$ & $0(0)$ & $0(0)$ \\
\hline L-F border & $9(26)$ & $23(92)$ & $8(73)$ & $3(17)$ \\
\hline F layer & $0(0)$ & $0(0)$ & $1(9)$ & $14(78)$ \\
\hline A layer & $0(0)$ & $2(8)$ & $2(18)$ & $1(6)$ \\
\hline
\end{tabular}


Osono Table 3

Table 3. Radiocarbon content in fruiting bodies of macrofungi. Samples from CT were from the lower slope.

\begin{tabular}{|c|c|c|c|c|c|c|c|}
\hline & Species & Soil layer & Collection date & Laboratory code & $\delta^{13} \mathrm{C}$ & $\Delta^{14} \mathrm{C}$ & Carbon age (yr) \\
\hline \multirow[t]{3}{*}{$\mathrm{ST}$} & Mycena sp. ST1 & L layer & Apr 11 & IAAA-111556 & $-27.3 \pm 0.5$ & $48.2 \pm 2.8$ & 2.8 \\
\hline & Gymnopus sp. ST1 & L layer & Oct 11 & IAAA-111557 & $-30.4 \pm 0.5$ & $52.0 \pm 3.0$ & 4.5 \\
\hline & Marasmius sp. ST4 & $\mathrm{L}-\mathrm{F}$ border & Oct 11 & IAAA- 111558 & $-22.9 \pm 0.4$ & $68.6 \pm 2.7$ & 9.0 \\
\hline \multirow[t]{3}{*}{$\mathrm{CT}$} & Mycena polygramma & $\mathrm{L}-\mathrm{F}$ border & Oct 01 & IAAA-81685 & $-25.5 \pm 0.3$ & $132.6 \pm 3.7$ & 9.5 \\
\hline & Mycena amygdalina & L-F border & Nov 11 & IAAA-111554 & $-20.2 \pm 0.4$ & $79.6 \pm 2.8$ & 11.4 \\
\hline & Gymnopus peronatus & L-F border & Nov 01 & IAAA-111555 & $-24.3 \pm 0.4$ & $91.0 \pm 2.7$ & 3.6 \\
\hline \multirow[t]{3}{*}{$\mathrm{SA}$} & Mycena aurantiidisca & L-F border & Oct 08 & IAAA-81687 & $-24.9 \pm 0.4$ & $96.0 \pm 3.8$ & 11.3 \\
\hline & Mycena epipterygia & L-F border & Oct 11 & IAAA-111552 & $-23.0 \pm 0.4$ & $139.7 \pm 2.8$ & 20.3 \\
\hline & Galerina atkinsoniana & L-F border & Oct 11 & IAAA- 111553 & $-28.9 \pm 0.4$ & $56.7 \pm 2.7$ & 5.9 \\
\hline
\end{tabular}


Osono Table 4

Table 4. Size of fruiting bodies of macrofungi. DP, diameter of pileus; LS, length of stipe. Values are means \pm standard errors in $\mathrm{cm}$. Numbers in parentheses indicate the number of samples. The same letters indicate that the values are not significantly different at 5\% level by Tukey's HSD test. Data from CT are from the lower slope.

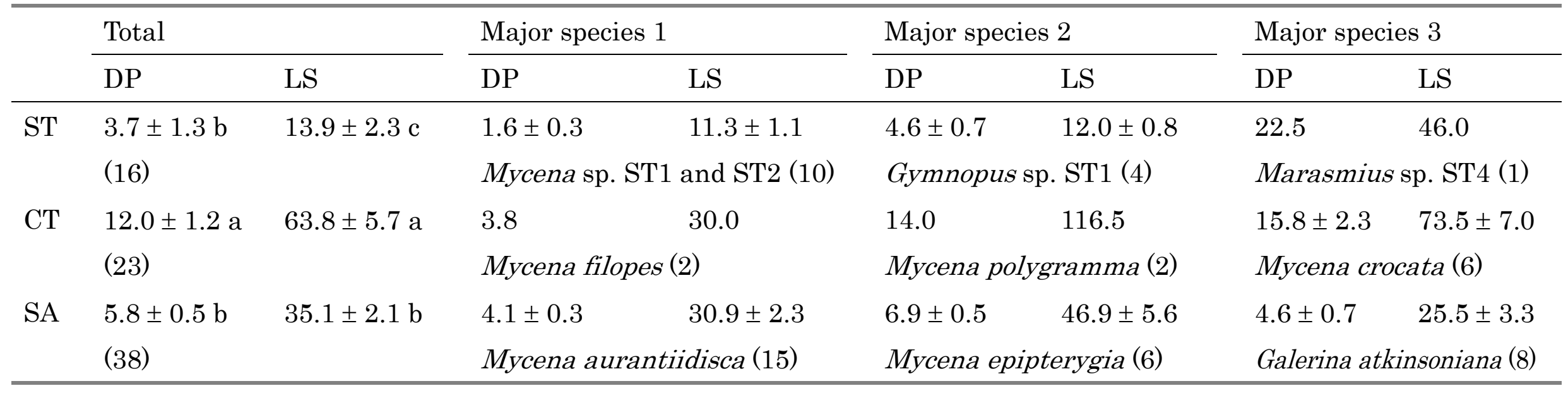


1 Figure legends

2

3 Fig. 1. Rank-relative frequency distribution of macrofungal assemblages in 4 subtropical (ST), cool temperate (CT), and subalpine forests (SA). Open, 5 Mycenaceae; filled, Marasmiaceae; coarse oblique mesh, Agaricaceae; fine oblique 6 mesh, Tricholomataceae; horizontal mesh, others (Hygrophoraceae,

7 Hymenogasteraceae, Pluteaceae, Psathyrellaceae, Strophariaceae, Xylariaceae,

8 and unidentified). The survey in CT was performed at lower and upper parts of a 9 forest slope.

11 Fig. 2. Seasonal changes in the frequency of occurrence (upper) and the number of 12 species (lower) of fruiting bodies of macrofungi. $\square$, subtropical forest (ST); $\bigcirc$, 13 lower part of a slope in cool temperate forest, [CT (lower)]; O, upper part of a slope 14 in cool temperate forest [CT (upper)]; $\boldsymbol{\Delta}$, subalpine forest (SA).

16 Fig. 3. Seasonal changes in the frequency of occurrence of major macrofungal 17 species in subtropical forest (ST), cool temperate forest (CT), and subalpine forest 18 (SA). For CT, blank and shaded bars indicate lower and upper slopes, respectively. 
1 Osono Fig. 1

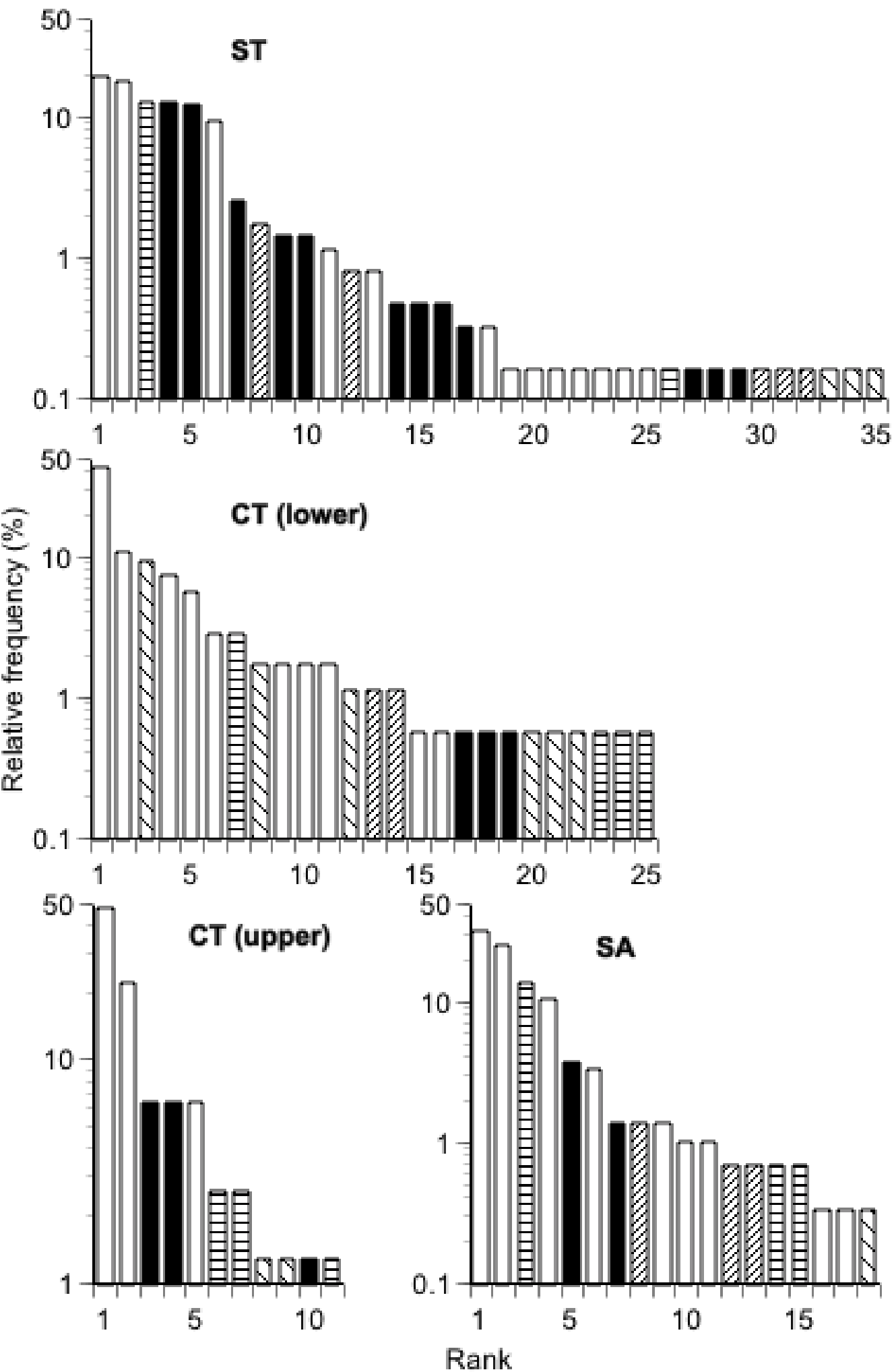


1 Osono Fig. 2

2
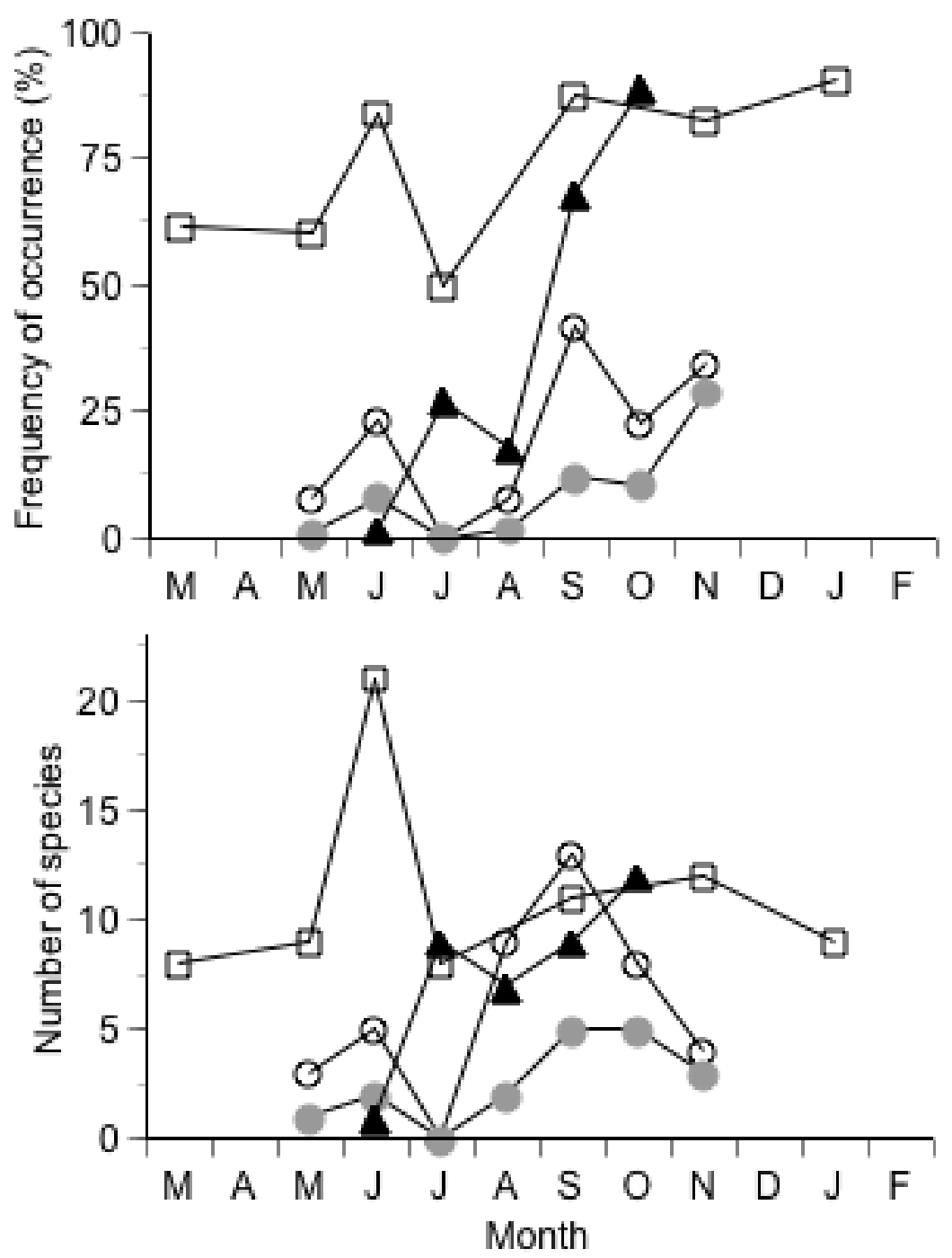
1 Osono Fig. 3
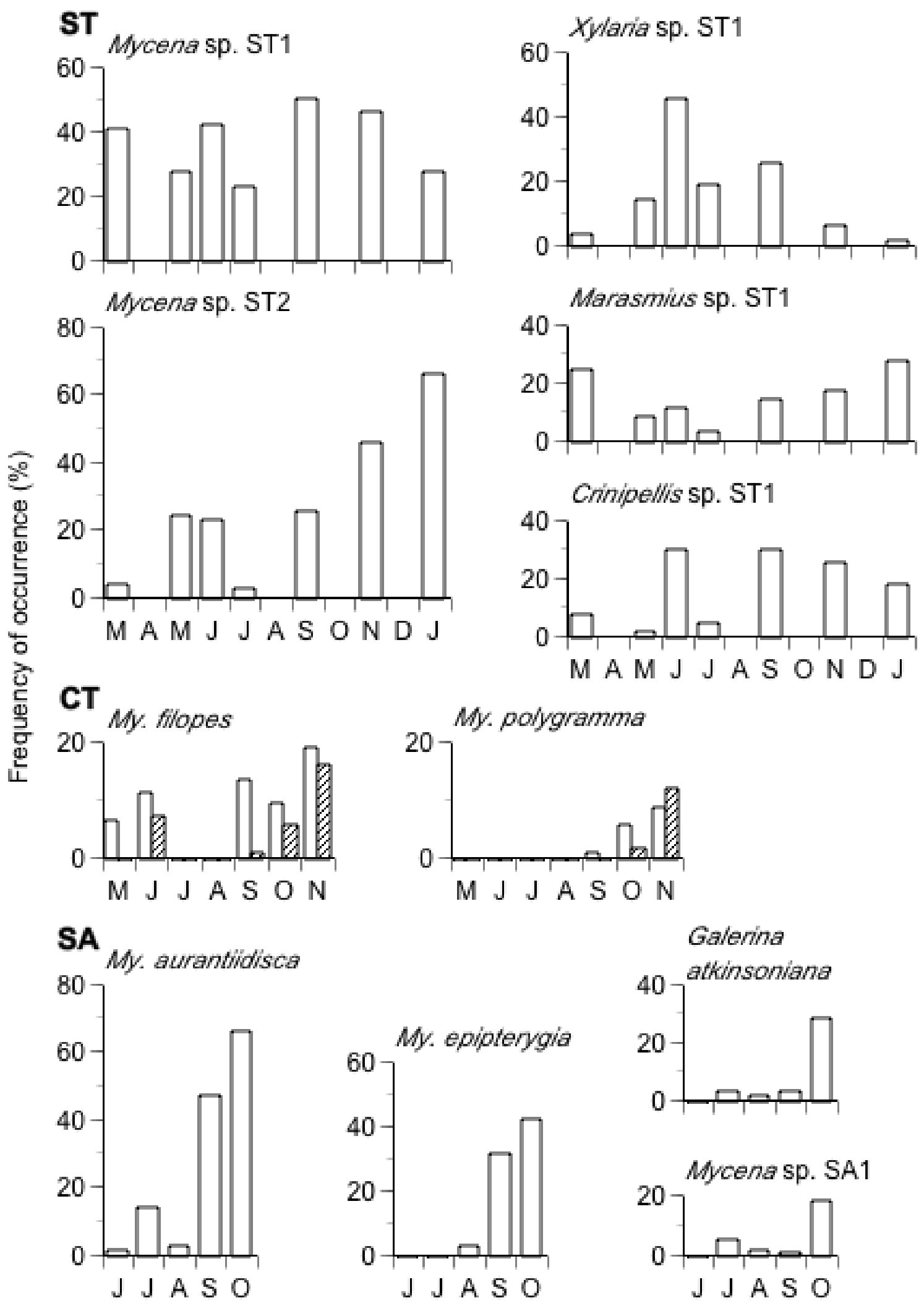

SA $M y$. aurantiidisca
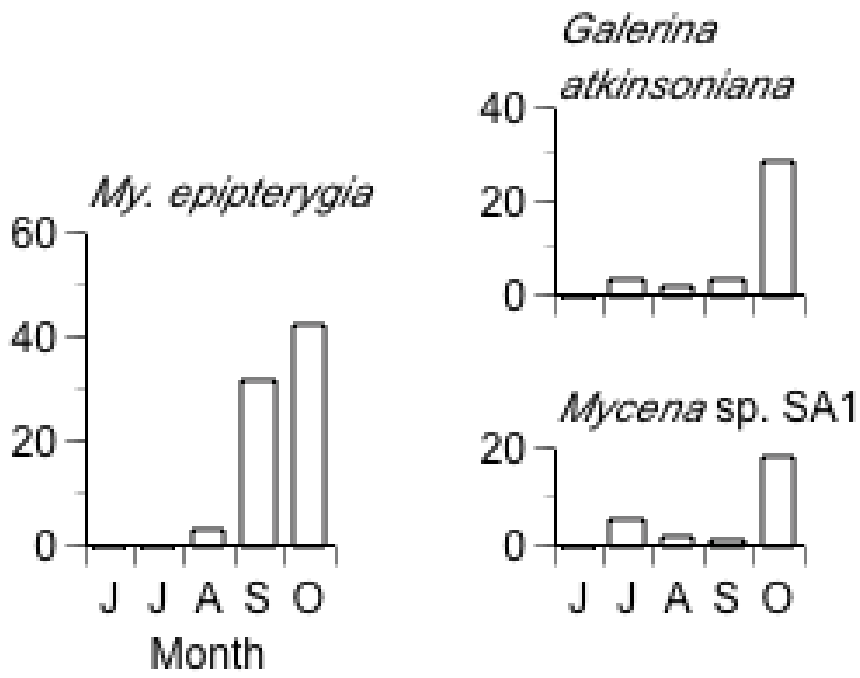


\section{Electronic Supplementary Material}

Patterns in diversity, resource utilization, and phenology of fruiting bodies of litter-decomposing macrofungi in subtropical, temperate, and subalpine forests

Takashi Osono

Table S1: Frequency of occurrence of fruiting bodies of macrofungi and the soil layer from which the fruiting bodies occurred. Ag, Agaricaceae; Hg, Hygrophoraceae; Hm, Hymenogasteraceae; Mr, Marasmiaceae; My, Mycenaceae; Tr, Tricholomataceae; Pl, Pluteaceae; Ps, Psathyrellaceae; St, Strophariaceae; Xy, Xylariaceae; and Un, unidentified. L/F, L-F border.

\begin{tabular}{llll}
\hline Taxa & Family & Soil layer & Frequency (\%) \\
\hline Subtropical forest & & & \\
Mycena section Basipedes 'sp. ST1' & $\mathrm{My}$ & $\mathrm{L}$ & 96.8 \\
Mycena section Roridae 'sp. ST2' & $\mathrm{My}$ & $\mathrm{L}$ & 90.4 \\
Xylaria spp. ST1 & $\mathrm{Xy}$ & $\mathrm{L}$ & 64.8 \\
Marasmius spp. ST1 & $\mathrm{Mr}$ & $\mathrm{L}$ & 63.2 \\
Crinipellis sp. ST1 & $\mathrm{Mr}$ & $\mathrm{L}$ & 60.8 \\
Mycena sp. ST3 & $\mathrm{My}$ & $\mathrm{L}$ & 46.4 \\
Gymnopus sp. ST1 & $\mathrm{Mr}$ & $\mathrm{L}$ & 12.8 \\
Tricholomataceae sp. ST1 & $\mathrm{Tr}$ & $\mathrm{A}$ & 8.8 \\
Gymnopus sp. ST2 & $\mathrm{Mr}$ & $\mathrm{L}$ & 7.2 \\
Marasmiellus sp. ST1 & $\mathrm{Mr}$ & $\mathrm{L}$ & 7.2 \\
Mycena sp. ST4 & $\mathrm{My}$ & $\mathrm{L}$ & 5.6 \\
Tricholomataceae sp. ST2 & $\mathrm{Tr}$ & $\mathrm{A}$ & 4.0 \\
Mycena sp. ST5 & $\mathrm{My}$ & $\mathrm{L}$ & 4.0 \\
Crinipellis sp. ST2 & $\mathrm{Mr}$ & $\mathrm{L}$ & 2.4 \\
Gymnopus sp. ST3 & $\mathrm{Mr}$ & $\mathrm{L}$ & 2.4 \\
cf. Calyptella sp. ST1 & $\mathrm{Mr}$ & $\mathrm{L}$ & 2.4 \\
\hline
\end{tabular}




\begin{tabular}{|c|c|c|c|c|}
\hline Marasmius sp. ST2 & $\mathrm{Mr}$ & $\mathrm{L}$ & 1.6 & \\
\hline Mycena sp. ST6 & My & $\mathrm{L}$ & 1.6 & \\
\hline Agaricaceae sp. ST1 & $\mathrm{Ag}$ & A & 0.8 & \\
\hline Agaricaceae sp. ST2 & $\mathrm{Ag}$ & $\mathrm{A}$ & 0.8 & \\
\hline Gymnopus sp. ST4 & $\mathrm{Mr}$ & $\mathrm{L}$ & 0.8 & \\
\hline Mycena sp. ST7 & My & $\mathrm{L}$ & 0.8 & \\
\hline Leucocorpinus sp. ST1 & Ag & A & 0.8 & \\
\hline Marasmiellus sp. ST2 & $\mathrm{Mr}$ & $\mathrm{A}$ & 0.8 & \\
\hline Marasmiellus sp. ST3 & $\mathrm{Mr}$ & $\mathrm{L}$ & 0.8 & \\
\hline Mycena sp. ST8 & My & $\mathrm{L}$ & 0.8 & \\
\hline Mycena sp. ST9 & My & $\mathrm{L}$ & 0.8 & \\
\hline Mycena sp. ST10 & My & $\mathrm{L}$ & 0.8 & \\
\hline Unidentified ST1 & Un & $\mathrm{L}$ & 0.8 & \\
\hline Mycena sp. ST11 & My & $\mathrm{A}$ & 0.8 & \\
\hline Mycena sp. ST12 & My & $\mathrm{L}$ & 0.8 & \\
\hline Tricholomataceae sp. ST3 & $\operatorname{Tr}$ & $\mathrm{A}$ & 0.8 & \\
\hline Tricholomataceae sp. ST4 & $\operatorname{Tr}$ & A & 0.8 & \\
\hline Tricholomataceae sp. ST5 & $\operatorname{Tr}$ & $\mathrm{L}$ & 0.8 & \\
\hline Xeromphalina sp. ST1 & My & $\mathrm{L}$ & 0.8 & \\
\hline Cool temperate forest & & & Upper & Lower \\
\hline Mycena amygdalina & My & $\mathrm{L} / \mathrm{F}$ & 29.6 & 60 \\
\hline Mycena polygramma & My & $\mathrm{L} / \mathrm{F}$ & 13.6 & 15.2 \\
\hline Gymnopus peronatus & $\mathrm{Mr}$ & $\mathrm{L} / \mathrm{F}$ & 4.0 & 0.8 \\
\hline Gymnopus sp. CT1 & $\mathrm{Mr}$ & $\mathrm{L} / \mathrm{F}$ & 4.0 & 0.0 \\
\hline Mycena sp. CT2 & My & $\mathrm{L} / \mathrm{F}$ & 4.0 & 0.0 \\
\hline Stropharia aeruginosa & St & $\mathrm{L} / \mathrm{F}$ & 1.6 & 0.8 \\
\hline Hygrocybe cantharellus & Hy & $\mathrm{L} / \mathrm{F}$ & 1.6 & 0.0 \\
\hline Agaricaceae sp. CT1 & $\mathrm{Ag}$ & $\mathrm{L} / \mathrm{F}$ & 0.8 & 0.0 \\
\hline Lepiota fusciceps & $\mathrm{Ag}$ & $\mathrm{F}$ & 0.8 & 0.0 \\
\hline Marasmius sp. CT2 & $\mathrm{Mr}$ & A & 0.8 & 0.0 \\
\hline Naematoloma sublateritium & St & A & 0.8 & 0.0 \\
\hline Lycoperdon perlatum & $\mathrm{Ag}$ & A & 0.0 & 12.8 \\
\hline
\end{tabular}




\begin{tabular}{|c|c|c|c|c|}
\hline Mycena pura & My & $\mathrm{L} / \mathrm{F}$ & 0.0 & 10.4 \\
\hline Mycena sp. CT1 & My & $\mathrm{L} / \mathrm{F}$ & 0.0 & 8.0 \\
\hline Mycena amicta & My & $\mathrm{L} / \mathrm{F}$ & 0.0 & 4.0 \\
\hline Psathyrella candolleana & Ps & $\mathrm{L} / \mathrm{F}$ & 0.0 & 4.0 \\
\hline Agariaceae sp.CT2 & $\mathrm{Ag}$ & $\mathrm{L} / \mathrm{F}$ & 0.0 & 2.4 \\
\hline Mycena crocata & My & $\mathrm{L} / \mathrm{F}$ & 0.0 & 2.4 \\
\hline Mycena luteopallens & My & $\mathrm{L} / \mathrm{F}$ & 0.0 & 2.4 \\
\hline Mycena sp. CT3 & My & $\mathrm{L} / \mathrm{F}$ & 0.0 & 2.4 \\
\hline Agaricus praeclaresquamosus & $\mathrm{Ag}$ & $\mathrm{L} / \mathrm{F}$ & 0.0 & 1.6 \\
\hline Clitocybe sp. CT1 & $\mathrm{Mr}$ & $\mathrm{L} / \mathrm{F}$ & 0.0 & 1.6 \\
\hline Pseudoclitocybe cyathiformis & $\operatorname{Tr}$ & $\mathrm{L} / \mathrm{F}$ & 0.0 & 1.6 \\
\hline Lepiota cf. pseudogranulosa & $\mathrm{Ag}$ & $\mathrm{L} / \mathrm{F}$ & 0.0 & 0.8 \\
\hline Lepiota cygnea & $\mathrm{Ag}$ & $\mathrm{L} / \mathrm{F}$ & 0.0 & 0.8 \\
\hline Lepiota sp. CT1 & $\mathrm{Ag}$ & A & 0.0 & 0.8 \\
\hline Marasmius pulcheriipes & $\mathrm{Mr}$ & $\mathrm{L} / \mathrm{F}$ & 0.0 & 0.8 \\
\hline Marasmius sp. CT1 & $\mathrm{Mr}$ & $\mathrm{L} / \mathrm{F}$ & 0.0 & 0.8 \\
\hline Mycena cf. osmundicola & My & $\mathrm{L} / \mathrm{F}$ & 0.0 & 0.8 \\
\hline Mycena sp. CT4 & My & $\mathrm{L} / \mathrm{F}$ & 0.0 & 0.8 \\
\hline Psathyrella piluliformis & Ps & $\mathrm{L} / \mathrm{F}$ & 0.0 & 0.8 \\
\hline Volvariella speciosa var. gloiocephala & $\mathrm{Pl}$ & $\mathrm{L} / \mathrm{F}$ & 0.0 & 0.8 \\
\hline \multicolumn{5}{|l|}{ Subalpine forest } \\
\hline Mycena aurantiidisca & My & $\mathrm{F}$ & 75.2 & \\
\hline Mycena epipterygia & My & $\mathrm{F}$ & 60.8 & \\
\hline Galerina atkinsoniana & $\mathrm{Hm}$ & $\mathrm{F}$ & 32.8 & \\
\hline Mycena cf. filopes & My & $\mathrm{L} / \mathrm{F}$ & 24.8 & \\
\hline Clitocybe sp. SA1 & $\mathrm{Mr}$ & $\mathrm{F}$ & 8.8 & \\
\hline Mycena sp. SA2 & My & $\mathrm{L} / \mathrm{F}$ & 8.0 & \\
\hline Marasmius androsaceus & $\mathrm{Mr}$ & $\mathrm{L} / \mathrm{F}$ & 3.2 & \\
\hline Tricholomataceae sp. SA1 & $\operatorname{Tr}$ & $\mathrm{F}$ & 3.2 & \\
\hline Mycena cf. stipata & My & $\mathrm{F}$ & 3.2 & \\
\hline Mycena sp. SA3 & My & $\mathrm{F}$ & 2.4 & \\
\hline Mycena cf. pura & My & $\mathrm{F}$ & 2.4 & \\
\hline
\end{tabular}




\begin{tabular}{lccc}
\hline Collybia cookei & Tr & F & 1.6 \\
Tricholomataceae sp. SA2 & Tr & F & 1.6 \\
Unidentified SA1 & Un & F & 1.6 \\
Unidentified SA2 & Un & F & 1.6 \\
Mycena sp. SA5 & My & F & 0.8 \\
Mycena sp. SA4 & My & F & 0.8 \\
Lycoperdon perlatum & $\mathrm{Ag}$ & $\mathrm{A}$ & 0.8 \\
\hline
\end{tabular}

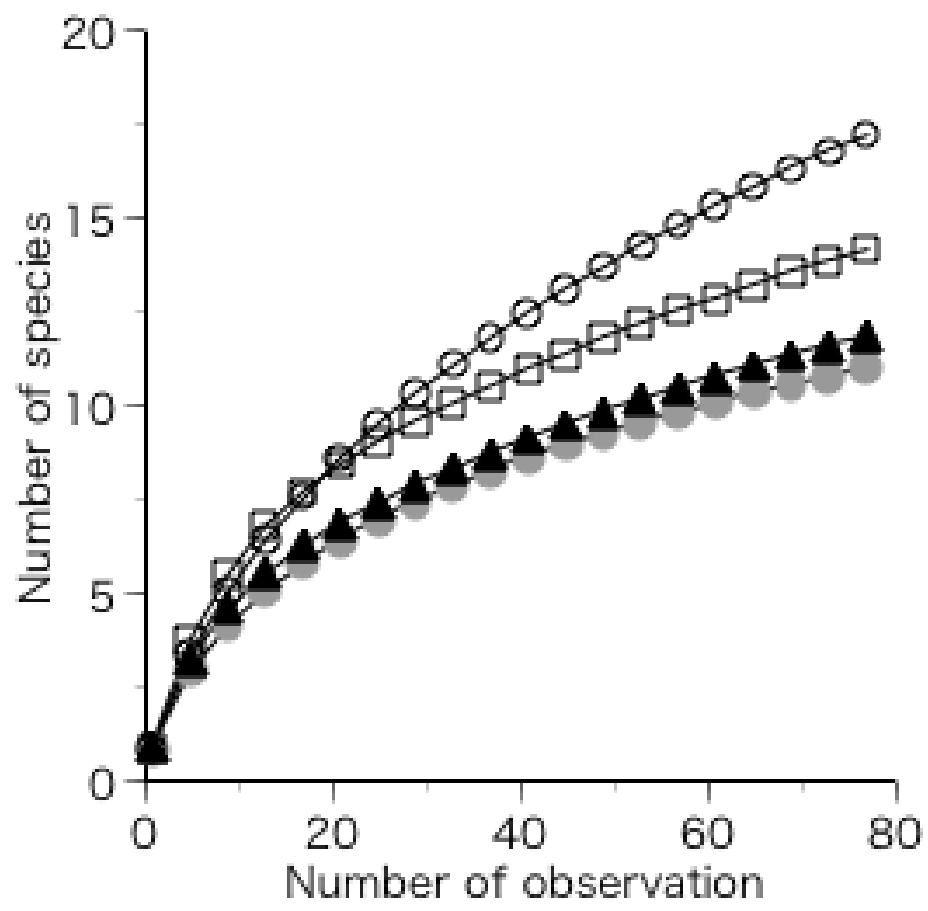

Fig. S2. Rarefaction curves for litter-decomposing macrofungal (LDM) assemblages. $\square$, subtropical forest (ST); O, lower part of a slope in cool temperate forest, [CT (lower)]; , upper part of a slope in cool temperate forest [CT (upper)]; $\Delta$, subalpine forest (SA). 